\title{
The role of inhibins and activins in prostate cancer pathogenesis
}

\author{
$C$ R Dowling and G P Risbridger
}

Institute of Reproduction and Development, Monash University, Monash Medical Centre, 246 Clayton Road, Clayton, Victoria 3168, Australia

(Requests for offprints should be addressed to G P Risbridger, Monash Institute of Reproduction and Development, 27-31 Wright Street, Clayton, Victoria 3168, Australia; Email:

gail.risbridger@med.monash.edu.au)

\begin{abstract}
Successful prostate cancer diagnosis and management continue to provide challenges for the clinician. While interventions aimed at the containment of both early and late disease continue to fail in a significant number of patients, the search for answers must incorporate an analysis of the processes of normal and aberrant growth and development within the gland itself. Inhibin and its structurally related protein, activin, are members of the transforming-growth-factor $\beta$ (TGF $\beta$ ) superfamily. Originally identified as regulators of $\mathrm{FSH}$, these proteins are now recognised to have widespread biological functions. This might be expected of proteins that are structurally homologous to TGF $\beta$ itself, which is recognised to have regulatory roles in both normal and malignant prostate tissue. The aim of this review is to examine the relationship between inhibins, activins and their related proteins and the development of prostate cancer. The homology with TGF, the pluripotent effects of activin on various tissues and the roles for inhibins in ovarian cancer make activins and inhibins candidate growth factors for involvement at multiple sites in the progression from benign disease to cancer. In compiling this review, we aim to delineate the changes in inhibins and activins in this pathway and in doing so implicate their potential roles in the progression of carcinogenesis. We will compare the changes in inhibin and its related proteins in prostate cancer to those that are known in ovarian cancer. We will discuss the similarities and differences between the putative role of activins and TGF $\beta$ in prostate carcinogenesis. The importance of this review lies in demonstrating that inhibin, an endocrine hormone, and its related proteins may contribute to endocrine-related cancers, such as that of the prostate gland.
\end{abstract}

\section{Introduction}

Prostate cancer is the most frequently diagnosed cancer in men in the developed world, excluding skin cancers, and is the second commonest cause of cancer-related death in men after lung cancer. Despite these important statistics, it is a misguided perception that prostate cancer does not represent as great a health problem for the male population as breast cancer does for the female population. This may be because prostate cancer affects men about a decade later in life than breast cancer affects women. In the USA the average age at diagnosis for carcinoma of the prostate is 71 years and for breast carcinoma 64 years (SEER 1973-1991). Whilst there are a few cases of prostate cancer in older men that may not significantly shorten their life, men who are diagnosed with the disease in their sixties have an $80 \%$ chance of dying as a direct result of their cancer (Aus \& Hugosson 1997, Johansson et al. 1997).
Efforts to significantly halt the progress of prostate cancer have been frustrated by lack of a highly sensitive and specific screening tool to detect cancer at a stage at which it is confined within the gland, and by the lack of an effective treatment with minimal morbidity. For the urologist, significant progress in patient management would be possible if a method existed to allow prediction of those cases that might progress from apparently organ-confined disease, and therefore require active management. Additionally, identifying those cases in which it may be appropriate for conservative management is a significant clinical challenge. The importance of determining the role of endocrine and paracrine control mechanisms in normal development and carcinogenesis in the prostate cannot be overstated. Their identification is likely to prove crucial in any future ability to target the disease earlier, to initiate new therapies, to select cases that are more likely to be aggressive, and to control the disease once it reaches androgen independence. 


\section{Pathways of prostate carcinogenesis, roles for growth factors and justification for the study of inhibin and activin in cancer}

In 1941, Huggins \& Hodges discovered that prostate development and disease was driven by androgens. Whilst a direct role for androgens in the stimulation of cancer growth is recognised, their indirect actions via growth factors and cytokines, including transforming-growth factor $\beta$ (TGF $\beta$ ) and fibroblast growth factor, is an emerging field. It is also conceivable that growth factors will have roles that are both androgen dependent and androgen independent, possibly providing potential sites of intervention in androgenindependent disease, which is currently refractory to treatment. Therefore, there is motivation for the search for these different regulatory proteins, including members of the TGF $\beta$ superfamily, which is widely recognised to have a role in carcinogenesis. Many growth factors, including TGF $\beta$, are implicated in the pathogenesis of other cancers (Blobe et al. 2000). The receptors for TGF $\beta$ ligands and the signalling proteins comprise a tumour-suppressor pathway in carcinogenesis (Fig. 1) and development of resistance to TGF $\beta$ by tumour cells represents a key event in the progression of malignancy (Kim et al. 2000).

While the specific involvement of TGF $\beta$ in the pathogenesis of cancer is accepted, the case for inhibin and activin is less distinct. Inhibin and activin have normal biological roles distinct from those of TGF $\beta$. Inhibin is involved in reproductive regulation and activin has reproductive roles and also regulates crucial phases of development, such as mesoderm induction and dorsoventral patterning. Inhibins and activins are also important in branching morphogenesis and the reader is referred to a review of this work (Risbridger \& Cancilla 2000). There is potential, however, for inhibin and activin to function in other biological systems in a manner similar to TGF $\beta$ and indeed redundancy may exist. Activins and inhibins have been identified in tumours as diverse as prostate, ovarian, pancreatic, pituitary, breast and the gastrointestinal tract. It is possible, then, that the roles of activins and inhibins may prove to be of similar importance to TGF $\beta$ during carcinogenesis, particularly in the case of activin. While inhibin may have roles in the pathogenesis of other endocrine-related cancers, in particular breast cancer, currently little is known about breast cancer in the context of inhibins and activins (Di Loreto et al. 1999, McCluggage \& Maxwell 1999).

Inhibin is known to be a serum marker in some subtypes of ovarian cancer and levels of immunoreactive inhibin are elevated in almost all patients with granulosa cell tumours and the majority of postmenopausal women with mucinous ovarian carcinoma (Burger et al. 1998). While the elevation of serum inhibin $\alpha$ subunits is associated with the development of ovarian cancer, the cellular pathways to tumour development in ovarian carcinoma that involve inhibin and its related proteins are not fully understood.

Further evidence for the potential importance of TGF $\beta$ superfamily proteins in carcinogenesis is supported by the role of bone morphogenic proteins (BMPs). These members of the TGF $\beta$ superfamily both have roles in the regulation of bone remodelling and are expressed in a variety of non-skeletal sites, consistent with possible wider roles in diverse tissues (Paralkar et al. 1998). Inhibins and the related proteins, activins, are members of the TGF $\beta$ growth factor superfamily and demonstrate $30 \%$ structural homology with TGFß (Mason et al. 1986). Whilst inhibin is recognised to function as an endocrine hormone (de Kretser \& McFarlane 1996), the related activin dimers have important roles in growth, differentiation and development. As we shall discuss, many of these roles comprise important steps in cancer progression, including effects on wound healing and tissue repair, immune function and regulation of the cardiovascular system. These characteristics make it reasonable to suggest that activin may have an important role in the development and progression of cancer.

\section{Defining prostatic inhibin}

The existence of additional proteins such as inhibin with capabilities of regulating follicle-stimulating hormone (FSH) was predicted as long as 60 years ago. McCullagh's demonstration of the suppression of anterior pituitary or 'castration' cells by bovine testicular fluid raised the idea that the FSH system was subject to endocrine influences beyond those that were already recognised (McCullagh 1932).

In the 1980s seminal plasma was used as a source of material for purification programmes and inhibin activity was identified in this biological fluid (Beksac et al. 1984). When the inhibin genes were isolated and cloned in the1980s it was revealed that the inhibin protein in seminal plasma was not related to dimeric inhibin (Robertson et al. 1985, Mason et al. 1986). In fact, seminal plasma inhibin is a major secretory product of the prostate and represents about $20 \%$ of total secreted protein in seminal plasma. It is distinct from dimeric inhibin, because it is a single chain polypeptide of 94 amino acids. In reviewing the body of literature referring to inhibin it is important to clarify this point, in order to avoid any further confusion. Different authors have reported seminal plasma inhibin as inhibin or prostatic inhibin peptide, $\beta$-microseminoprotein, immunoglobulin-binding factor and prostatic secretory protein of 94 amino acids. Over almost two decades evidence has accumulated to show that this protein is a major secretory product of the prostatic epithelium and that its expression may be altered in benign and malignant tissues and cell lines (Teni et al. 1988). There is some evidence that it may be a useful biomarker of 

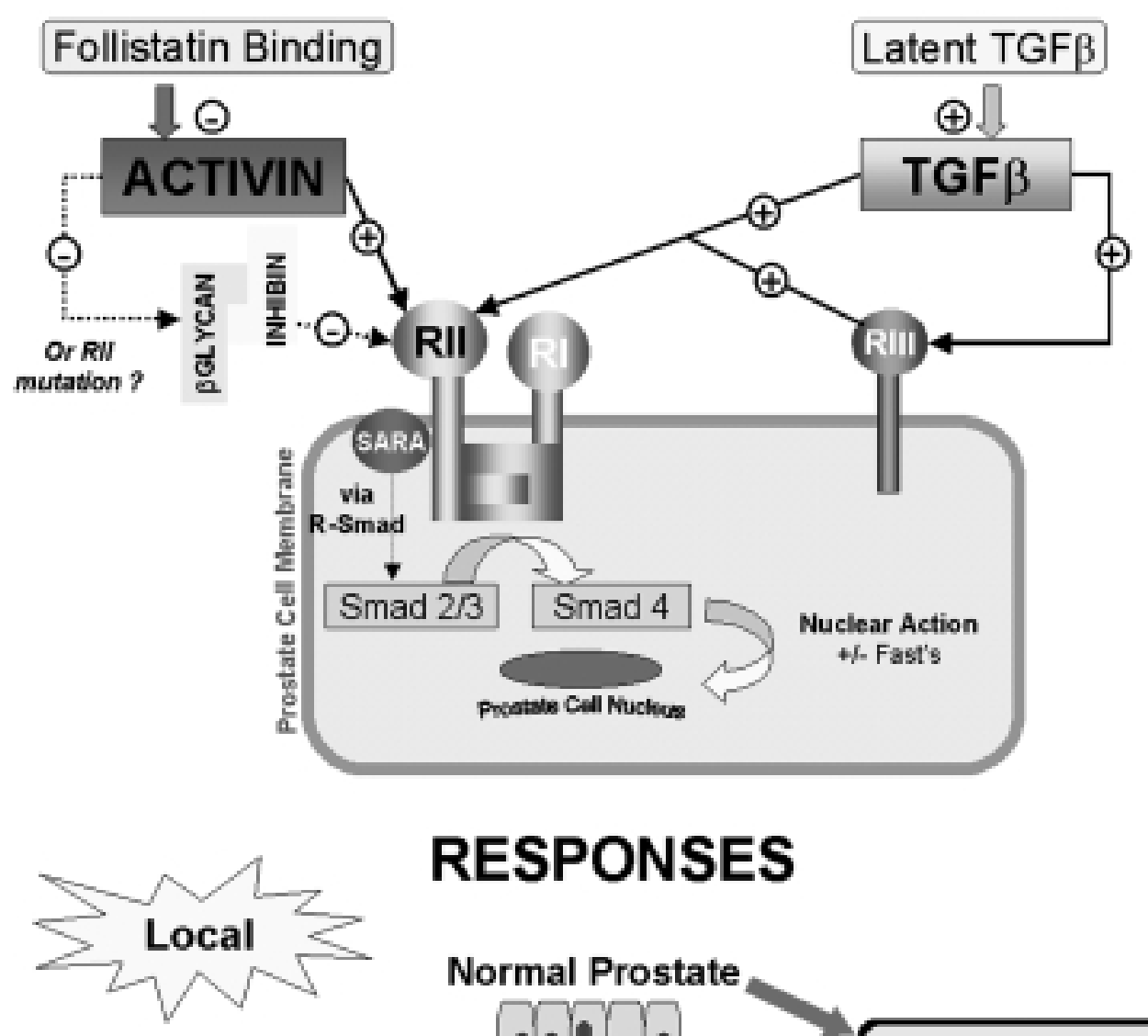

\section{RESPONSES}

\section{Normal Prostate}
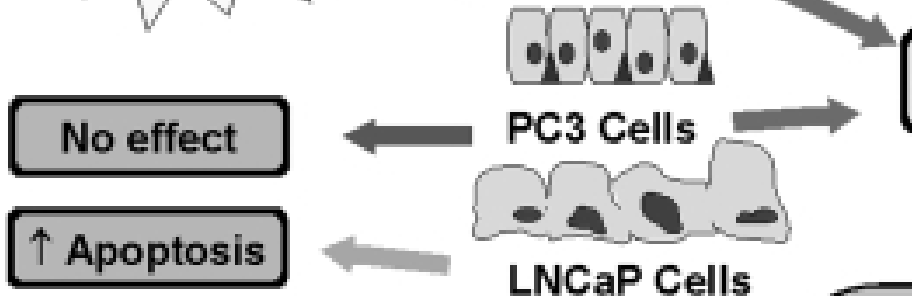

Growth Inhibitory

\section{LNCaP Cells}

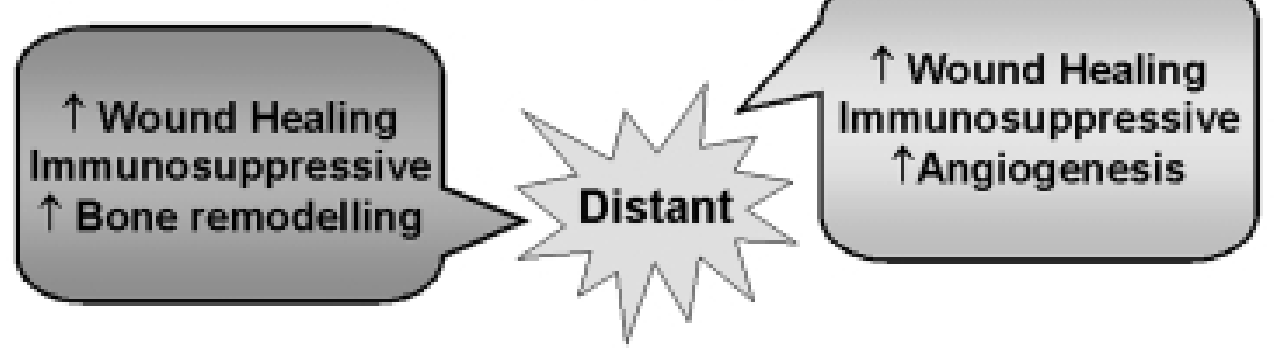

Figure 1 Summary of some of the similarities and differences between activin and TGF $\beta$ ligands. Activin's receptor binding and local and distant effects are shown on the left-hand side of the figure. Those of TGF $\beta$ are on the right-hand side. The two ligands have similar receptor activation mechanisms, through classes of receptors that contain a serine/threonine kinase domain. Intracellularly, the Smad proteins are involved in both systems. Before receptor binding, TGF $\beta$ is activated from a latent form. Activin is active but may be modified either by follistatin binding or through dominant negative receptor binding by inhibin and betaglycan. Activin RII receptor component mutations, similar to that known to involve components of the TGF $\beta$ receptor, have been suggested to occur. Alterations in Smad proteins are also implicated in the pathway to carcinogenesis. The 'responses' to activin and TGF $\beta$ are 'local' or 'distant' as indicated. Local responses are shown as their effects on normal cells, LNCaP and PC3 prostate cancer cell lines. The distant effects are similar for wound healing and immunosuppression. Activin has a more defined role in bone remodelling and TGF $\beta$ is known to have angiogenic properties. 
prostate cancer, but the review of that literature is outside the scope of this article (Garde et al. 1994).

\section{The inhibin and activin ligands}

Mature inhibin is a 31 to $32 \mathrm{kDa}$ heterodimeric glycoprotein. Two forms exist, both containing the common $\beta$ subunit (18 $\mathrm{kDa})$ joined to a subunit $(14 \mathrm{kDa})$ by disulphide bridges. The two most commonly recognised $\beta$ subunits are $\beta_{\mathrm{A}}$ and $\beta_{\mathrm{B}}$. Dimerisation with the $\alpha$ subunit leads to the formation of inhibin $A\left(\alpha \beta_{A}\right)$ and inhibin $B\left(\alpha \beta_{B}\right)$ (Burger 1988, Ying 1988). Activin proteins are formed by the dimerisation of the $\beta$ subunits, $\beta_{\mathrm{A}}$ and $\beta_{\mathrm{B}}$. Specific roles of the various subunits are incompletely defined but differential expression of the subunits in tissues may lead to preferential formation of particular activin proteins. Dimerisation results in three protein combinations, namely activin $A\left(\beta_{\mathrm{A}} \beta_{\mathrm{A}}\right)$, activin $\mathrm{B}$ $\left(\beta_{B} \beta_{B}\right)$ and activin $A B\left(\beta_{A} \beta_{B}\right)$. Where it has been possible to measure the level of the individual ligands in differing biological situations, such as the menstrual cycle and pregnancy, changes have been demonstrated (McLachlan et al. 1987).

Additional $\beta$ subunits, $\beta_{\mathrm{C}}, \beta_{\mathrm{D}}$ and $\beta_{\mathrm{E}}$, have been characterised. The $\beta_{\mathrm{C}}$ and $\beta_{\mathrm{E}}$ subunits have been cloned from mouse (Fang et al. 1996, Lau et al. 1996). The $\beta_{D}$ subunit has been cloned from Xenopus but no mammalian equivalent has yet been described (Oda et al. 1995). We have recently reported that $\beta_{C}$ dimerises, forming activin $C$. However, studies have failed to demonstrate dimerisation of $\beta_{\mathrm{C}}$ with the subunit and hence formation of a putative inhibin $\mathrm{C}\left(\alpha \beta_{\mathrm{C}}\right)$ (Mellor et al. 2000). It is not yet known if the formation of other dimers involving $\beta_{\mathrm{C}}, \beta_{\mathrm{D}}$ and $\beta_{\mathrm{E}}$ occurs.

\section{Inhibin and activin receptors and signalling}

Knowledge of the TGF $\beta$ receptor, which contains serine/ threonine kinase domains, has helped to characterise the initial steps in the mechanism of activin interaction with its receptor. Delineation of an intracellular signalling pathway for inhibin awaits unequivocal proof of a receptor for inhibin, about which controversy regarding its very existence persists. The evidence presented supporting the existence of an inhibin receptor is based on the identification of specific binding sites for inhibin on ovarian granulosa cells and Leydig cells (Woodruff et al. 1990, 1993, Krummen et al. 1994). Additional supporting data for the existence of a specific receptor include the demonstration of an inhibin-specific protein complex, $\mathrm{k} 562$, in haematopoietic cell lines (Lebrun \& Vale 1997) and tumour-derived inhibin receptor proteins in the Matzuk inhibin knockout mice (Draper et al. 1998).

In contrast to these findings, it is suggested that inhibin does not act through a receptor, but exerts its effect through a dominant negative mechanism. This hypothesis was initially put forward after the report that inhibin A had no activity of its own in liver cell growth and that it served principally to inhibit the anti-proliferative action of activin A on HepG2 cells (Xu et al. 1995). Xu and colleagues proposed that inhibin antagonised the effect of activins by blocking activin-receptor binding. This mechanism was recently re-evaluated, as a result of the report that the type III TGF $\beta$ receptor, betaglycan, can function as a co-receptor with specific activin type II (ActRII or ActRIIB) receptor serine kinases (Lewis et al. 2000). Specifically, it was proposed that betaglycan facilitated the antagonism of activin action by inhibin. Some support for this hypothesis was drawn by analogy with the mechanism of control of the melanocyte-stimulating hormone (MSH) ligand. For MSH action, the proteoglycan, mahogany, acts as the betaglycan does for inhibin, by facilitating binding of the MSH antagonist, agouti, to the $\mathrm{MSH}$ receptor. Hence it was proposed that inhibin and betaglycan bind and block ligand (activin) access to the receptor, just as the binding of agouti to mahogany blocks the access of MSH to its receptor, resulting in a dominant negative disruption of the $\mathrm{MSH}$ signal (Gunn et al. 1999, Nagle et al. 1999).

The activin receptor is typical of the TGF $\beta$ superfamily, being comprised of two structurally related classes of receptors (type I and type II), both containing a serine/ threonine kinase domain (Mathews \& Vale 1991). The type I and type II components are composed of single membrane spanning subunits designated type RI (50-55 kDa) and type RII (70-75 kDa) (Mathews 1994). The receptor mediates ligand action after the RII component trans-phosphorylates the RI domain (Fig. 1). Phosphorylation of RII is not necessary for downstream signalling but RII must bind RI in order for signalling to occur. RII can bind activin alone. Mutations of both the RI and RII components have been described but mutations of single residues in RI fail to inhibit activity. Analogous conclusions can be drawn from mutational analysis of TGF $\beta$ receptor subunits (Woodruff 1998). It is recognised that prostate cancer cells may reduce the expression of TGF $\beta$ receptor subunits (T $\beta R$-I or T $\beta R$-II) in order to escape the growth-inhibitory effects of TGF $\beta$ (Lee et al. 1999). Whilst this binary receptor is similar for all ligands of the TGF $\beta$ superfamily, discrimination between the different ligands is high and is determined by differential binding to the RII component (Woodruff 1998). For activin, there are two known ligand-binding type II receptor genes, type II and type IIB.

A common model for intracellular signalling involving activin and other TGF $\beta$ superfamily proteins is via intracellular heterodimeric and homodimeric Smad (Sma genes and mothers against dpp (Mad)) proteins (Fig. 1). Smads are the direct cytoplasmic substrates for the TGF $\beta$ superfamily. Smad2 is involved in the pathway for both TGF $\beta$ and activin signalling (Lagna et al. 1996, Wu et al. 
1997). The role of Smads in mediation of cancer phenotypes is not clear in prostate disease, but it is known that deletion of genetic material in the region required for the production of Smads is seen in other human adenocarcinomas, such as pancreatic and colorectal cancer (Eppert et al. 1996, Hahn et al. 1996) and it may be that similar changes occur in the development of prostatic malignancy.

Further effectors of TGF $\beta$ superfamily intracellular signalling include the Smad anchor for activation (SARAs) and the forkhead DNA-binding proteins (FASTs). SARAs present Smad2 and Smad3 to the activated type 1 receptor (ten Dijke et al. 2000). Ectopic expression of SARA mutants interfere with TGF $\beta$ signalling (Tsukazaki et al. 1998) and provide another point at which aberrant signalling could lead to carcinogenesis. The affinities of Smad proteins for DNA is low (Shi et al. 1998). The FAST group of proteins are therefore required to act as binding factors for the interaction of Smads with DNA, including the case of FAST-1 and Smad4 in the cellular response to activin (Chen et al. 1997). Mutations of the DNA binding sites have been shown to attenuate the response of TGF $\beta$ (ten Dijke et al. 2000). It is therefore conceivable they have a role in tumour formation.

\section{Follistatins}

In addition to mediating their actions via receptor signalling, activin and inhibin are known to associate with binding proteins such as $\alpha 2$-macroglobulin (Vaughan \& Vale 1993). However, the most well known and functionally important interaction is between activins and follistatins. Follistatins are structurally distinct from inhibin and activin. Follistatins are glycosylated proteins now recognised to be members of a larger group of proteins with a well-conserved secondary structure that has a 'follistatin' domain that is rich in cysteine. Other proteins that are members of this group include agrin, secreted protein rich in cysteine (SPARC, also known as BM40 and osteonectin), testican, hevin and follistatin-related protein (Phillips \& de Kretser 1998). Nine molecular weight forms of follistatin are postulated, based on a core protein with a varying degree of glycosylation, and six have been identified (Sugino et al. 1993). The structure of follistatin is highly conserved between species, with a two amino acid difference between rat and human protein and 95\% structural homology in mammals (Phillips \& de Kretser 1998). Follistatins arise from two alternatively spliced mRNAs (FS288 and FS315, containing 288 and 315 amino acids respectively). In the prostate, their cellular distributions differ, with FS288 isolated principally to basal cells and FS315 to stromal cells (Thomas et al. 1998).

Follistatins exhibit an inhibin-like suppression of FSH (Robertson et al. 1987) and have affinity for inhibin and activin via the $\beta$ subunit (Shimonaka et al. 1991). The interaction of follistatins with activins is its most commonly recognised biological action, but a possible individual role in angiogenesis has also been suggested (Kozian et al. 1997). Follistatin also exerts biological effects through the binding of other TGF $\beta$ superfamily proteins, the BMPs (Yamashita et al. 1995, Fainsod et al. 1997).

\section{Inhibin, activin and prostate cancer Inhibins and prostate cancer}

The majority of current knowledge of the activins and inhibins in human cancer relates to ovarian and prostate cancer. The focus in ovarian cancer has been on the role of the inhibin subunit (Lappohn et al. 1989). There is also an important role for inhibin and, in particular, its subunit in prostate cancer. Expression and localisation of inhibin and activin subunits in normal and benign prostate tissue have been defined using both immunohistochemistry and isolation of mRNA (Thomas et al. 1997). Based upon these findings, it is known that the normal distribution of proteins is altered in prostate disease and carcinogenesis.

Studies from this laboratory have shown that the human prostate synthesises dimeric inhibins and activins, including the inhibin subunit and A, B and C (Thomas et al. 1998b). In non-malignant tissue or benign prostatic hyperplasia (BPH), subunit mRNA was expressed, but detection of protein was more problematic because of antibody specificity. A commonly used Groome antibody did not demonstrate immunoreactivity; however, there was immunoreactivity to others, such as those raised to the carboxyl- and amino-terminal ( $\alpha_{C}$ and $\left.\alpha_{N}\right)$ regions of the $\alpha$ subunit terminal region (Mellor et al. 1998). Both inhibin A and B are secreted to seminal fluid (Anderson et al. 1998) but the relative ratios and function of the ligands are unknown and it is not known whether inhibin A or B represents the predominant form in the prostate.

\section{Loss of inhibin subunit expression}

Loss of expression of inhibin subunits in high-grade prostate cancer has been demonstrated by in situ hybridisation and immunoreactivity to antibodies that are able to determine the expression of subunits in normal prostate (see Fig. 2) (Mellor et al. 1998). Down-regulation of gene expression and the absence of mRNA or protein in tissues from high-grade disease was observed (Mellor et al. 1998). These data and the findings of gonadal tumour development in the Matzuk knockout mice (Matzuk et al. 1992) support the hypothesis that the inhibin $\alpha$ subunit has a role as a tumour suppressor in prostate cancer. Matzuk and colleagues first suggested a role for the inhibin subunits in carcinogenesis. Specifically, they proposed that the inhibin $\alpha$ subunit might act as a tumour suppressor because subunit knockout mice developed mixed or incompletely differentiated gonadal stromal tumours and, when castrated, adrenal tumours were noted to arise (Matzuk et al. 1992). 

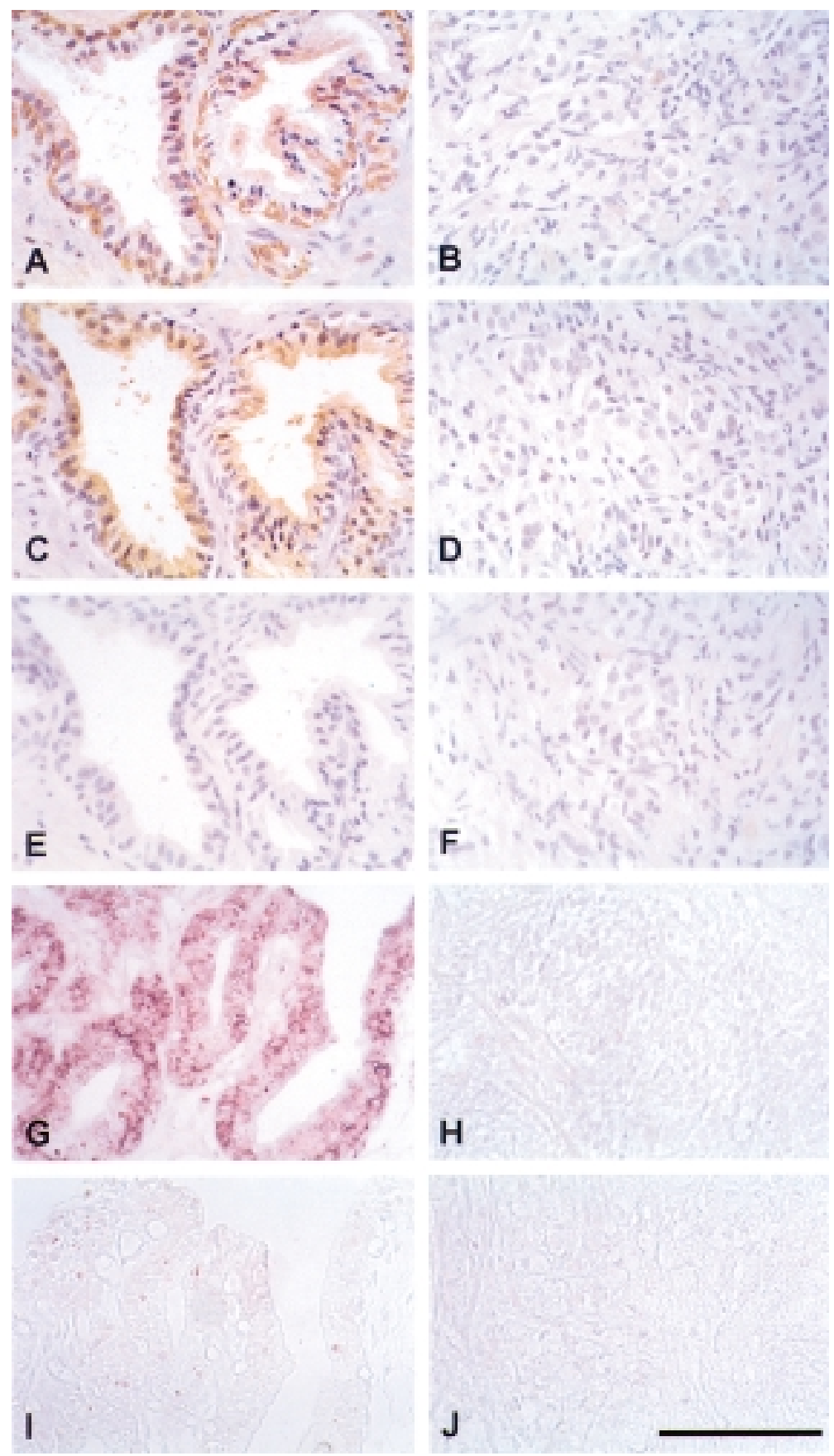

Figure 2 This demonstrates the loss of $\alpha$ subunit expression in high-grade prostate carcinoma. Localisation of $\alpha_{\mathrm{C}}$ and $\alpha_{\mathrm{N}}$ inhibin protein and inhibin $\alpha$ subunit mRNA to non-malignant and malignant regions of prostate tissues from patients with high-grade prostate cancer. $\alpha_{c}$ inhibin was localised to the basal epithelial cells in the non-malignant region $(A)$ of the prostate biopsy. The adjacent tumour cells displayed no immunoreactivity (B). Specific localisation of $\alpha_{N}$ protein was observed in the secretory epithelium of the non-malignant region (C); the adjacent tumour tissue displayed no staining (D). A control section was incubated with sheep $\lg G$ and displayed no specific immunoreactivity ( $E$ and $F$ ). $\alpha$ inhibin mRNA was expressed in basal epithelial cells in the non-malignant region $(G)$. The adjacent malignant region showed no immunolocalisation $(H)$. The control section incubated with the sense probe displayed no signal (I and J). Scale bar $=100 \mu \mathrm{m}$. (Reproduced with permission from Mellor et al. (1998) Journal of Clinical Endocrinology and Metabolism 83 973; Fig. 3.) 
The charactersitics of the prostates in Matzuk inhibin-deficient mice were not described. However, the primary sex cord stromal tumours lead to death in more than $95 \%$ of the male mice at 12 weeks. This is likely to be too early to see hyperplastic or neoplastic changes in the mouse prostate. The genetically manipulated mouse had not been a particularly useful way to study human prostate cancer because, in order to induce prostate cancer, most groups use Simian virus $40 \mathrm{~T}$-antigens plus or minus prostate specific promoters; these viral oncoproteins are not etiologic agents for prostate cancer and have multiple cellular actions. Furthermore, the mouse prostate has marked anatomical differences from the human prostate and therefore may not represent the ideal animal for the development of a model for human prostate cancer (Sharma \& Schreiber-Agus 1999).

In human cancers, the down-regulation of tumour suppressor genes may be associated with a loss of heterozygosity or promoter hypermethylation. Unpublished data from this laboratory show that both mechanisms occur in prostate cancer (JF Schmitt \& GP Risbridger). The inhibin gene was localised to the $2 \mathrm{q} 33$ chromosomal locus in the human genome and deletions on chromosome $2 \mathrm{q}$ occur in human tumours, including ovarian, bladder and hepatocellular carcinomas (Nagai et al. 1997, Saretzki et al. 1997, Watson et al. 1997). Frequent loss of chromosome 2 occurs and this region was identified as a candidate region in hereditary forms of prostate cancer (Alers et al. 2000, Suarez et al. 2000) although deletions for $2 \mathrm{q} 33$ have not been specifically reported.

In vitro data also support the loss of the $\alpha$ subunit. In cultured prostate cancer cell lines, there is no detectable inhibin $\alpha$ gene or protein expression in the $\mathrm{LNCaP}$ (androgen sensitive), DU145 (relatively androgen sensitive) and PC3 (androgen insensitive) lines (Thomas et al. 1997).

\section{In vitro studies and dominant negative receptor function}

The effect of exogenous inhibin on prostate cancer cell lines is conflicting. We have shown that there was no effect on cell growth with application of inhibin A to LNCaP, DU145 or PC3 prostate cancer cell lines (McPherson et al. 1997). While a small degree of decreased proliferation of the LNCaP cell line has been demonstrated with the addition of inhibin, this was at one-hundredth of the potency demonstrated with activin (Wang et al. 1996). Explanations offered for this minimal growth-inhibitory response include inhibin acting in either a dominant negative mechanism with the activin receptor, with greater affinity for the type IIB than type II component, or direct binding by inhibin of its own receptor. The dominant negative theory is supported by the mechanism already discussed, where inhibin can bind the type II moiety of the activin receptor, resulting in failure to then recruit the type I receptor to complete the complex (Draper et al. 1998). However, Wang et al. (1996) favour the concept of binding to an inhibin receptor, as the inhibin effect was additive to that demonstrated by activin and greater than predicted due to the interruption of activin receptor binding alone.

\section{Activins and prostate cancer}

There is little known about the role of activin in normal and non-malignant prostate tissue beyond the finding of expression of $\beta_{\mathrm{A}}$ and $\beta_{\mathrm{B}}$ subunits in the epithelium of non-malignant prostate disease and immunohistochemical demonstration of activin A expression by the epithelium of BPH (Thomas et al. 1997). In prostate cancer, in vitro studies have demonstrated the presence of $\beta_{\mathrm{A}}, \beta_{\mathrm{B}}$, and $\beta_{\mathrm{C}}$ subunits in all grades of cancer in the epithelial cells. The presence of $\beta_{A}$, $\beta_{\mathrm{B}}$, and $\beta_{\mathrm{C}}$ expressed in high-grade cancers, in the absence of inhibin $\alpha$ subunit expression, suggests that cells continue to synthesise activins.

So, what then is the role of activins in prostate cancer pathogenesis? The majority of current knowledge in answer to this question is obtained from in vitro studies on prostate cancer cell cultures and these lines do not exhibit a uniform response to activin $\mathrm{A}$.

\section{In vitro studies - an inconsistent response}

The local effects of activin A are demonstrated by studies on prostate cancer cell lines, LNCaP (androgen dependent), DU145 (relatively androgen dependent) and PC3 (androgen independent). A strong growth-inhibitory effect in response to activin $\mathrm{A}$ in the prostate cancer cell lines is only seen after addition of exogenous activin A to the $\mathrm{LNCaP}$ cell line (Dalkin et al. 1996, Wang et al. 1996, McPherson et al. 1997). This growth inhibition of cell proliferation and induction of apoptosis is dose dependent, and importantly is androgen independent (McPherson et al. 1997). Studies on the DU145 cell line demonstrated only an intermediate growth-inhibitory response to activin A and B with DU145 cells less affected than LNCaP at the same dose. Similar studies on the LNCaP line show an increased expression of prostate specific antigen, prostatic acid phosphatase and the androgen receptor itself occurred in the presence of exogenous activin (Zhang et al. 1997). These activities of activin on cell lines are subtype specific for the proteins as incubation with activin B demonstrated a lesser degree of inhibition than with activin A (Wang et al. 1996).

While activin was found to inhibit proliferation of the LNCaP and to a lesser extent the DU145 prostate cancer cell lines, no growth inhibition was seen in the PC3 cells (McPherson et al. 1997) and we conclude that PC3 cells are insensitive to activin A.

All three cell lines (LNCaP, DU145 and PC3) demonstrate production of $\beta_{\mathrm{A}}, \beta_{\mathrm{B}}$ and $\beta_{\mathrm{C}}$ subunit mRNA (McPherson et al. 1997). The use of specific enzyme-linked immunosorbent assays (ELISAs) for activin $\mathrm{A}$ have 
subsequently shown that there is production of dimeric activin $\mathrm{A}$ in measurable levels in cell lysates and from the cultured medium of PC3 prostate cancer cells but not from LNCaP cells (McPherson et al. 1999). This discovery is important in the explanation of local regulation of prostate cancer cells by activin, as we shall discuss.

\section{Activin in vivo}

The role of activins in carcinogenesis has also been studied in vivo. While the studies involving prostate cancer cell lines demonstrate convincing local growth inhibition in the LNCaP cells, activin has been shown to promote tumour growth in animal models. The combination of subunit knockout mice and p53 knockouts (with p53 acting as a tumour suppressor) lead to the development of a cell line that is growth stimulated by activin (Shikone et al. 1994). Transgenic mice expressing the Simian virus 40 T-antigens driven by the mouse inhibin subunit promoter establishes in vivo gonadal tumour models, which respond with growth promotion by activin stimulation (Kananen et al. 1995). These effects are likely to involve activin acting through paracrine rather than direct autocrine action such as that seen in the cell culture studies and are in keeping with activin's distant effects on immune function and carcinogenesis.

Endocrine tumours are characteristically hypervascularised; however, the cellular and molecular mechanisms of the angiogenesis process in these tumours is poorly understood (Dumortier et al. 1999). It is believed that both inactivation of anti-angiogenic mediators and activation of pro-angiogenic factors are involved in endocrine tumour angiogenesis. The precise mediators of this process and their mechanisms of action remain to be delineated. Although activin has not been directly demonstrated to play a role in the mediation of angiogenesis, it is known that activin can stimulate the growth of vascular smooth muscle cells in rats and is up-regulated after vascular injury in the setting of atherosclerosis (Molloy et al. 1999). There is strong induction of activin expression after skin injury and activin expression has been demonstrated in the repair processes of many tissues including skin, lung, intestine and the cardiovascular system. It is thought that the initial surge in activin, in response to inflammation, has a beneficial role but sustained activin activity may result in fibrosis (Munz et al. 1999).

Activin itself has not been characterised as a specific regulator of bone remodelling, but the related BMPs are expressed at high levels by the prostate. The BMP variant in the prostate is termed prostate-derived factor (PDF). PDF expression in the prostate is regulated by androgens (Paralkar et al. 1998). BMP-2 and BMP-6 were both identified in prostate cancers (Ide et al. 1997, Autzen et al. 1998, Thomas et al. 1998a). Interest in the role they might play in the pathogenesis of bony metastases in prostate cancer is under investigation.

\section{Activins and follistatins in prostate cancer}

The studies on the effects of activin on cell lines and the knowledge of similarities between activin and TGF $\beta$ have led to hypotheses to explain the mechanism by which prostate cancer cells overcome the growth-inhibitory effects of activin. PC3 tumour cells may acquire resistance to activin by functional alterations in the activin receptor, in a similar way to that by which tumour cells acquire resistance to TGF $\beta$ via its receptors. For example, production of an activin-blocking substance or abnormal post-receptor signalling has been proposed (Fig. 1) (Dalkin et al. 1996). Decreased expression of activin receptor mRNA levels for the ActRIB (type I) receptor component in malignant prostate tissue also supports the possibility that the acquisition of activin resistance in the PC3 cells is due to a receptor-related decrease in the local inhibitory effect of activin (van Schaik et al. 2000). However, receptor-related mechanisms have not been proven to be the exclusive cause of activin resistance demonstrated by PC3 cells.

Paracrine stromal-epithelial interactions are recognised regulatory mechanisms that exist in the prostate as recently reviewed (Grossfeld et al. 1998). In BPH, a normal stromal-epithelial relationship exists between the expression of activin and follistatin. Follistatin (FS315) immunoreactivity is expressed in the stroma and activin A predominantly in the epithelium (Thomas et al. 1998b). More specifically, the follistatin was localised to the fibroblastic but not the smooth muscle stromal elements. In contrast, non-malignant tissue from specimens that also contain prostate cancer show co-localisation of the activin and FS288 to the basal cell type (McPherson et al. 1999). This co-localisation supports the theory that follistatin neutralises the action of activin (see Fig. 3) and is supported by the finding that PC3 tumour cells produce measurable levels of FS288 and activin A protein in both cell lysates and the medium from cultured PC3 cells (McPherson et al. 1999). Both immunohistochemistry and Western blotting of prostate tumour cell lines have demonstrated the presence of follistatins. The distribution of the splice variants differs, with FS315 isolated in all lines, but FS288 was most prominent in the PC3 cells (McPherson et al. 1997). While the relative levels of the follistatins produced by the different cell lines remains to be shown, it is known that FS288 is secreted in large amounts by the PC3 cells but not LNCaP cells (Wang et al. 1996).

The significance of these findings may lie in the observation that FS288 has a greater neutralising effect on activin than FS315 (Sugino et al. 1993). The inhibitory effect of activin A can be blocked in both LNCaP and DU145 cells by the addition of a tenfold excess of FS288 protein. LNCaP cells demonstrate growth inhibition in response to exogenous activin A, which is reversible by the addition of follistatin (McPherson et al. 1997). In the PC3 cells it is currently 
suspected that activin's growth-inhibitory action is neutralised by follistatin production. This would be in the setting of autocrine regulation, favouring tumour growth. It would be interesting to speculate if stripping the prostate cancer cells (PC3) of their follistatin would result in growth
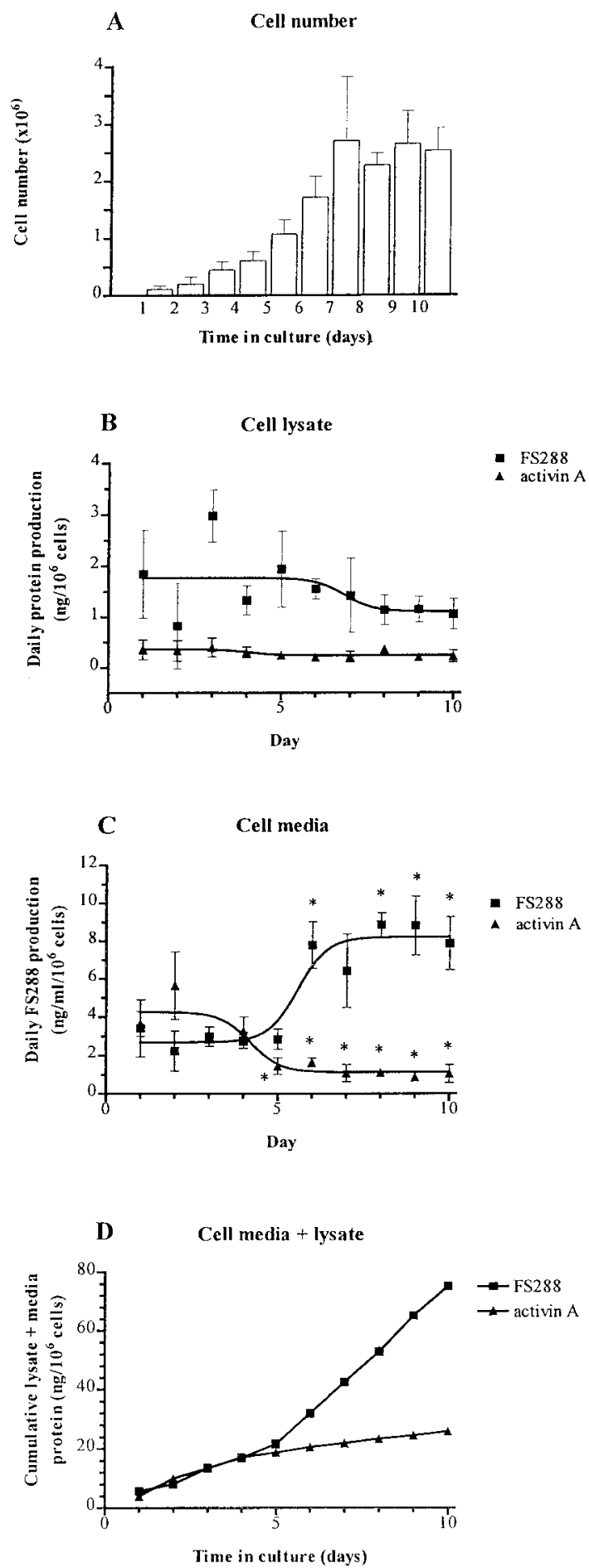

inhibition in response to local activin production, in a similar way to that which has been demonstrated in ovarian cancer cell lines (Di Simone et al. 1996, Delbaere et al. 1999). This response has been tested in a different way by treating the PC3 cell with a neutralising follistatin antibody to endogenous FS288. The addition of activin $\mathrm{A}$ and the antibody to FS288 in increasing concentrations resulted in a dose-dependent decrease in cell proliferation to approximately $60 \%$ of control values. This lends further support to the idea that FS288 production by PC3 cells renders them resistant to the growth-inhibitory effects of activin (McPherson et al. 1999).

A crucial future step in the further analysis of the activin/ follistatin interaction is examination of the effects in cell lines cultured from primary tumours as opposed to those from metastases from which LNCaP, DU145 and PC3 are all derived. Preliminary studies on explant primary cells and subcultured epithelial components have confirmed that the cells secreted activin and follistatin in a way similar to that which occurs in the cell lines above (Wang et al. 1999). Exogenous activin addition caused inhibition of proliferation in all cell lines cultured from primary tumours and this was neutralised by the addition of human recombinant follistatin (FS288). The Gleason grading of the 13 unselected carcinoma specimens was not specified and therefore the relative changes with tumour grade remain to be shown (Wang et al. 1999).

The role for follistatin as an individual regulatory protein in the pathogenesis of prostate cancer is unknown. The change in follistatin localisation described with regard to the high-grade prostate cancer cell lines is the most striking, but

Figure 3 This figure demonstrates the measurement of activin A and FS288 production by PC3 prostate tumour cell lines in order to show the effect of follistatin in blocking the inhibitory response exhibited by activin on other cell lines, such as LNCaP. Cell lysates and conditioned media were collected daily from LNCaP and PC3 cells in culture and activin A and FS288 levels were measured by specific ELISA testing. (A) Change in PC3 cell number over the course of the 10-day culture period. Values represent means \pm S.D. of five replicate wells. (B) Daily cellular content of activin A and FS288 (shown as ng protein $/ 10^{6}$ cells per day) in PC3 cell lysates collected at 24-h intervals over 10 days in culture. Values represent means \pm S.D. of five replicate wells.

(C) The daily activin A and FS288 levels measured in cell-conditioned media collected at 24-h intervals over 10 days in culture (ng protein $/ 10^{6}$ cells per day). ${ }^{*} P<0.05$ compared with activin A or FS288 levels on day 1. Values represent means \pm S.D. of four replicate wells. (D) The sum cumulative levels of activin A and FS288 produced by PC3 cells over the course of the culture (ng protein $/ 10^{6}$ cells). All figures are representative of three separate experiments. (Reproduced with permission from McPherson et al. (1999) Endocrinology 140 5305; Fig. 1.) 
this is thought to relate to co-localisation with activin and hence forms part of the overall activin/follistatin interaction. There are individual roles for the splice variants, with FS288 more dominantly expressed in the PC3 cells and having a greater affinity overall for activin. If a shift in expression of FS288 can be demonstrated between grades in primary cancers as opposed to cell lines, this may further delineate the role of this splice variant.

\section{Alternative mechanisms of resistance to activin action in prostate cancer cell lines}

Follistatin binding, with or without activin receptor mutations (Fig. 1), does not currently offer the complete explanation for the development of activin resistance in PC3 prostate cancer cell lines. The formation of novel activin dimers, such as activin $\mathrm{C}$, with different functional characteristics, is another mechanism by which the action of activin may be mitigated. While $\beta_{\mathrm{C}}$ subunit mRNA was identified in earlier work (Thomas et al. 1998b), it has only recently been cloned from DU145 tumour cells (Mellor et al. 2000). The cloned $\beta_{\mathrm{C}}$ is identical to that cloned from human liver, except for a substitution at amino acid 19 (in the signalling sequence) where cytosine was replaced by thymine. Co-transfection into human kidney 293 cells and the development of a monoclonal antibody to $\beta_{\mathrm{C}}$ has enabled the identification of novel activin dimers, including activin $\mathrm{C}$, activin $\mathrm{AC}$ and activin $\mathrm{BC}$. Immunoreactivity for $\beta_{\mathrm{A}}, \beta_{\mathrm{B}}$ and $\beta_{C}$ subunits is found in prostate cancer and there is co-localisation of the $\beta_{\mathrm{A}}$ and $\beta_{\mathrm{C}}$ subunit proteins as well as the $\mathrm{B}$ and $\mathrm{C}$ subunit proteins to basal cells. Activin $\mathrm{C}$ dimeric protein does not alter DNA synthesis of LNCaP cells (Mellor et al. 2000). However, it could be speculated that, through the heterodimerisation of $\beta_{\mathrm{A}}$ with $\beta_{\mathrm{C}}$, the levels of biologically active activin A may decline, inhibiting the antiproliferative effect of activin A on prostate tumour cells.

\section{Activins and TGF}

TGF $\beta$ has a recognised role in the regulation of prostate growth in normal homeostasis and disease states (Dalkin et al. 1996, Barrack 1999, Lee et al. 1999). In prostate cancer, TGF $\beta$ mRNA and binding sites are up-regulated after androgen withdrawal and before apoptosis occurs. TGF $\beta$ is known to inhibit the growth of DU145 and PC3 cell lines but also has proliferative as well as antiproliferative actions, as it increases the biological aggressiveness of Dunning rat prostate cancer cell lines (Steiner \& Barrack 1992). TGF $\beta$ actions are clearly complex and may depend on the interplay of multiple other processes, including the hormonal environment and receptor function. In comparison, activin has an effect in cell lines different from TGF $\beta$, as TGF $\beta$ causes rapid inhibition of the PC3 cells but not the LNCaP cells (Piek et al. 1997). The explanation offered for this difference is reduced expression of the TGF $\beta$ type I receptor in the LNCaP line. It is likely that both activin and TGF $\beta$ have some similar and additional different receptor resistance mechanisms. Unlike activin, TGF $\beta$ is secreted in a latent form and activational changes may dictate its biological responses.

In summary, the breadth of knowledge on the roles of activin and inhibin in prostate cancer is expanding. The key messages currently, regarding the involvement of inhibins and activins in prostate cancer, concern the possibility that the inhibin subunit acts as a tumour suppressor and that local resistance to activin is possible through its interaction with follistatin. In addition, activin has the capacity to mediate changes distantly that favour tumour progression. Some of activin's actions locally and distantly may prove to be similar to those of TGF $\beta$, but at present their effects on prostate cancer cell lines are recognisably different (Fig. 1).

\section{Conclusions}

Inhibin may act as a tumour suppressor in prostate cancer. It is relevant then to briefly revisit the role of inhibin in ovarian carcinoma where it is now recognised there are changes in expression of the various inhibin and activin subunits. While carcinoma of the prostate is histologically an adenocarcinoma in $95 \%$ of cases, there are several histological variants of ovarian carcinoma, broadly the surface epithelial—stromal tumours, the sex cord-stromal tumours and the germ cell tumours. Most is known about inhibin and its related proteins in the granulosa cell-group which is not the majority of tumours, or the more aggressive group clinically. In ovarian cancer, there is an overproduction of inhibin subunits, to the degree that, in the granulosa variant of ovarian carcinoma, it can be measured in serum and is used clinically as a marker of disease (Burger et al. 1998). The role of inhibin overproduction in ovarian cancer pathogenesis remains to be clarified.

New evidence is starting to emerge with regard to the more common epithelial variants of ovarian carcinoma, but it is restricted to studies of protein expression and not the effects of the proteins on pathogenesis. Cellular localisation studies for the various proteins in epithelial tumours, including benign and malignant groups, demonstrate inconsistent staining for inhibin, with the subunit only localised in mucinous adenoma and cystic tumour with borderline malignancy (Yamashita et al. 1999). Findings in relation to protein and mRNA expression of and A subunits in various tumour subtypes has led to the conclusion that epithelial proliferation may result from an early event of unbalanced expression of inhibin and activin subunits (Zheng et al. 1998).

While the exact roles of inhibin and activin remain to be defined, there are some parallels to the role of TGF $\beta$ superfamily proteins in prostate carcinoma, where $\alpha$ subunit 
expression changes with tumour development. However, the inconsistency between the observation that in prostate cancer the inhibin $\alpha$ subunit may be a tumour suppressor and is overproduced to the level that it is measurable in serum in ovarian cancer needs to be explained. In conclusion, the role of inhibins in these two endocrine-related cancers remains to be defined, but the differential expression of the $\alpha$ subunit in the different grades of prostate cancer and the different histological subtypes of ovarian cancer is clearly important in the process of transformation to malignancy.

Inhibin and activin have multiple known and potential roles in carcinogenesis. Their homology to TGF $\beta$ is an important factor in directing ongoing research programmes, particularly with regard to activin. It is unlikely that inhibin and activin have a dual opposing role in prostate cancer but their functions may be linked if inhibin mediates some of its actions via a dominant negative mechanism at the activin receptor. Future directions in inhibin research include genetic analysis of the mechanisms of subunit loss in high-grade disease, the search for further clues regarding its role as a tumour suppressor and the final conclusion regarding the existence of a receptor.

Activins share many similarities with TGF. They have the same mechanism of receptor recruitment and intracellular signalling utilising the Smad proteins. They share common functions in regulation of the proliferation and differentiation of cells, embryonic development, wound healing, immune function and angiogenesis. They both demonstrate the ability to inhibit cell proliferation and, importantly, when this function is disturbed the normal pattern of cell growth is not maintained, paving the way for carcinogenesis. While activin produces cellular inhibition in $\mathrm{LNCaP}$ prostate tumour cell lines, this response is not uniform. Further investigation of activin may show that its role is more in keeping with the escape from normal regulation by TGF $\beta$ superfamily proteins, which occurs once cancer cells are able to resist TGF-mediated growth inhibition, allowing uncontrolled proliferation. Certainly the distant effects of activin and the TGF $\beta$ isoforms involved in the establishment and progression of carcinogenesis are similar. However, activin differs from TGF $\beta$ in development, specifically due to the roles activin plays in early embryogenesis with crucial actions in mesoderm induction and dorsoventral patterning, while TGF $\beta$ is responsible for more specific changes including cardiac, lung and craniofacial and urogenital defects. Activin's relationship with follistatin is a unique regulatory pathway, because an exact corollary for TGF $\beta$ has not been demonstrated. The interplay between TGF $\beta$ and its binding proteins occurs at a pre-activation stage and not through binding of the active ligand, such as is seen between activin and follistatin. Finally, activin has specific roles in reproduction with known changes during the menstrual cycle, pregnancy and parturition. TGF $\beta$ has not been investigated in this context.
There are overwhelming similarities that outweigh the differences between activin and TGF. What remains to be seen is the degree to which the functions of activin and TGF $\beta$ are complementary, synergistic or additive. It is also possible that their functions incorporate an element of redundancy in biological systems that would have important implications for any therapeutic interventions that were specifically targeted at one or other mediator. The continuing analysis of the function of activins in settings such as prostate cancer may answer this question.

Activin is growth inhibitory in some prostate tumour cell lines in vitro. The loss of activin's local or autocrine growth-inhibitory capacity in high-grade disease is most probably due to its interaction with follistatin and more specifically the FS288 splice variant. Activin also mediates actions more distantly in a paracrine capacity that would favour prostate tumour growth and the extra-prostatic role for activin may be of greater significance in the development of high-grade prostate cancer. Activin is likely to be a key player in local and distant disease development. Greater knowledge of its role in cytological and physiological prostate development may further define its potential to act as a mediator, particularly in an androgen-independent state.

Once the roles for inhibins, activins and follistatins are defined in prostate development and disease, their relative expression may provide markers for prognosis and, providing they prove to have some specificity of function distinct from that of TGF, they have potential roles in therapeutic interventions.

\section{Acknowledgements}

The authors wish to thank Mr D Moss, Dr C Hovens and Dr D Phillips for assistance with the manuscript and Sally Mellor and Stephen McPherson for assistance with the manuscript and figures.

\section{References}

Alers J, Rochat J, Krijtenburg PJ, Hop WC, Kranse R, Rosenberg C, Tanke HJ, Schroder FH \& van Dekken H 2000 Identification of genetic markers for prostatic cancer progression (in process citation). Laboratory Investigation 80 931-942.

Anderson RA, Evans LW, Irvine DS, McIntyre MA, Groome NP \& Riley SC 1998 Follistatin and activin A production by the male reproductive tract. Human Reproduction 13 3319-3325.

Aus G \& J Hugosson J 1997 Fifteen-year survival with prostate cancer in Sweden (letter; comment). Journal of the American Medical Association 278 205-206.

Autzen P, Robson CN, Bjartell A, Malcolm AJ, Johnson MI, Neal DE \& Hamdy FC 1998 Bone morphogenic protein 6 in skeletal metastases from prostate cancer and other common human malignancies. British Journal of Cancer 78 1219-1223.

Barrack ER $1999 \mathrm{TGFb}$ in prostate cancer: a growth inhibitor that can enhance tumorigenicity. Prostate 31 61-70. 
Beksac MS, Khan SA, Eliasson R, Skakkebaek NE, Sheth AR \& Diczfalusy E 1984 Evidence for the prostatic origin of immunoreactive inhibin-like material in human seminal plasma. International Journal of Andrology 7 389-397.

Blobe GC, Schiemann WP \& Lodish HF 2000 Role of transforming growth factor beta in human disease. New England Journal of Medicine 342 1350-1358.

Burger HG 1988 Inhibin: definition and nomenclature, including related substances. Journal of Endocrinology 117 159-160.

Burger HG, Baillie A, Drummond AE, Healy DL, Jobling T, Mamers P, Robertson DM, Susil B, Cahir N, Shen Y, Verity K, Fuller PJ, Groome NP \& Findlay JK 1998 Inhibin and ovarian cancer. Journal of Reproductive Immunology 39 77-87.

Chen X, Weisberg E, Fridmacher V, Watanabe M, Naco G \& Whitman M 1997 Smad4 and FAST-1 in the assembly of activin-responsive factor. Nature $\mathbf{3 8 9} 85-89$.

Dalkin AC, Gilrain JT, Bradshaw D \& Myers CE 1996 Activin inhibition of prostate cancer cell growth: selective actions on androgen-responsive LNCaP cells. Endocrinology 137 52305235.

Delbaere A, Sidis Y \& Schneyer AL 1999 Differential response to exogenous and endogenous activin in a human ovarian teratocarcinoma-derived cell line (PA-1): regulation by cell surface follistatin. Endocrinology 140 2463-2470.

ten Dijke P, Miyazono K \& Heldin CH 2000 Signaling inputs converge on nuclear effectors in TGFbeta signaling. Trends in Biochemical Sciences 25 64-70.

Di Loreto C, Reis FM, Cataldi P, Zuiani C, Luisi S, Beltrami CA \& Petraglia F 1999 Human mammary gland and breast carcinoma contain immunoreactive inhibin/activin subunits: evidence for a secretion into cystic fluid. European Journal of Endocrinology 141 190-194.

Di Simone N, Crowley WF Jr, Wang QF, Sluss PM \& Schneyer AL 1996 Characterization of inhibin/activin subunit, follistatin, and activin type II receptors in human ovarian cancer cell lines: a potential role in autocrine growth regulation. Endocrinology 137 486-494.

Draper LB, Matzuk MM, Roberts VJ, Cox E, Weiss J, Mather JP \& Woodruff TK 1998 Identification of an inhibin receptor in gonadal tumors from inhibin alpha-subunit knockout mice. Journal of Biological Chemistry 273 398-403.

Dumortier J, Ratineau C, Roche C, Lombard-Bohas C, Chayvialle JA \& Scoazec JY 1999 Angiogenesis and endocrine tumours. Bulletin du Cancer 86 148-153.

Eppert K, Scherer SW, Ozcelik H, Pirone R, Hoodless P, Kim H, Tsui LC, Bapat B, Gallinger S, Andrulis IL, Thomsen GH, Wrana JL \& Attisano L 1996 MADR2 maps to 18q21 and encodes a TGFbeta-regulated MAD-related protein that is functionally mutated in colorectal carcinoma. Cell 86 543-552.

Fainsod A, Deissler K, Yelin R, Marom K, Epstein M, Pillemer G, Steinbeisser H \& Blum M 1997 The dorsalizing and neural inducing gene follistatin is an antagonist of BMP-4. Mechanisms of Development 63 39-50.

Fang J, Yin W, Smiley E, Wang SQ \& Bonadio J 1996 Molecular cloning of the mouse activin beta E subunit gene. Biochemical and Biophysical Research Communications 228 669-674.

Garde SV, Sheth AR, Venkatesan VM, Panchal CJ, Porter AT \& Grignon DJ 1994 Prostate inhibin peptide (PIP) in prostate cancer: a comparative immunohistochemical study with prostate-specific antigen (PSA) and prostatic acid phosphatase (PAP). Cancer Letters 78 11-17.
Grossfeld GD, Hayward SW, Tlsty TD \& Cunha GR 1998 The role of stroma in prostate carcinogenesis. Endocrine-Related Cancer 5 253-270.

Gunn TM, Miller KA, He L, Hyman RW, Davis RW, Azarani A, Schlossman SF, Duke-Cohan JS \& Barsh GS 1999 The mouse mahogany locus encodes a transmembrane form of human attractin. Nature 398 152-156.

Hahn SA, Schutte M, Hoque AT, Moskaluk CA, da Costa LT, Rozenblum E, Weinstein CL, Fischer A, Yeo CJ, Hruban RH \& Kern SE 1996 DPC4, a candidate tumor suppressor gene at human chromosome 18q21.1 (see comments). Science 271350 353.

Huggins C \& Hodges CV 1941 Studies in prostate cancer. I. The effects of castration, of estrogen and of androgen injection of serum phophatases in metastatic carcinoma of the prostate. Cancer Research 1 293-297.

Ide H, Yoshida T, Matsumoto N, Aoki K, Osada Y, Sugimura T \& Terada M 1997 Growth regulation of human prostate cancer cells by bone morphogenetic protein-2. Cancer Research $\mathbf{5 7}$ 5022-5027.

Johansson JE, Holmberg L, Johansson S, Bergstrom R \& Adami HO 1997 Fifteen-year survival in prostate cancer. A prospective, population-based study in Sweden (see comments). (Published erratum appears in Journal of the American Medical Association 1997278 206.) Journal of the American Medical Association 277 467-471.

Kananen K, Markkula M, Rainio E, Su JG, Hsueh AJ \& Huhtaniemi IT 1995 Gonadal tumorigenesis in transgenic mice bearing the mouse inhibin alpha-subunit promoter/simian virus T-antigen fusion gene: characterization of ovarian tumors and establishment of gonadotropin-responsive granulosa cell lines. Molecular Endocrinology 9 616-627.

Kim S-J, Im Y-H, Markowitz SD \& Bang Y-J 2000 Molecular mechanisms of inactivation of TGF $\beta$ beta receptors during carcinogenesis. Cytokine and Growth Factor Reviews 11159 168.

Kozian DH, Ziche M \& Augustin HG 1997 The activin-binding protein follistatin regulates autocrine endothelial cell activity and induces angiogenesis. Laboratory Investigations 76 267-276.

de Kretser DM \& McFarlane JR 1996 Inhibin in the male. Journal of Andrology 17 179-182.

Krummen LA, Moore A, Woodruff TK, Covello R, Taylor R, Working P \& Mather JP 1994 Localization of inhibin and activin binding sites in the testis during development by in situ ligand binding. Biology of Reproduction 50 734-744.

Lagna G, Hata A, Hemmati-Brivanlou A \& Massague J 1996 Partnership between DPC4 and SMAD proteins in TGF-beta signalling pathways. Nature $\mathbf{3 8 3} 832-836$.

Lappohn RE, Burger HG, Bouma J, Bangah M, Krans M \& de Bruijn HW 1989 Inhibin as a marker for granulosa-cell tumors (see comments). New England Journal of Medicine 321 790793.

Lau AL, Nishimori K \& Matzuk MM 1996 Structural analysis of the mouse activin beta $\mathrm{C}$ gene. Biochimica et Biophysica Acta 1307 145-148.

Lebrun JJ \& Vale WW 1997 Activin and inhibin have antagonistic effects on ligand-dependent heteromerization of the type I and type II activin receptors and human erythroid differentiation. Molecular and Cellular Biology 17 1682-1691.

Lee C, Sintich SM, Mathews EP, Shah AH, Kundu SD, Perry KT, Cho JS, Ilio KY, Cronauer MV, Janulis L \& Sensibar JA 1999 
Transforming growth factor-beta in benign and malignant prostate. Prostate 39 285-290.

Lewis KA, Gray PC, Blount AL, MacConell LA, Wiater E, Bilezikjian LM \&Vale W 2000 Betaglycan binds inhibin and can mediate functional antagonism of activin signalling. Nature $\mathbf{4 0 4}$ 411-414.

McCluggage WG \& Maxwell P 1999 Adenocarcinomas of various sites may exhibit immunoreactivity with anti-inhibin antibodies. Histopathology 35 216-220.

McCullagh D 1932 Dual endocrine activity of the testis. Science 76 19-20.

McLachlan RI, Robertson DM, Healy DL, Burger HG \& de Kretser DM 1987 Circulating immunoreactive inhibin levels during the normal human menstrual cycle. Journal of Clinical Endocrinology and Metabolism 65 954-961.

McPherson SJ, Thomas TZ, Wang H, Gurusinghe CJ \& Risbridger GP 1997 Growth inhibitory response to activin A and B by human prostate tumour cell lines, LNCaP and DU145. Journal of Endocrinology 154 535-545.

McPherson SJ, Mellor SL, Wang H, Evans LW, Groome NP \& Risbridger GP 1999 Expression of activin A and follistatin core proteins by human prostate tumor cell lines. Endocrinology 140 5303-5309.

Mason AJ, Niall HD \& Seeburg PH 1986 Structure of two human ovarian inhibins. Biochemical and Biophysical Research Communications 135 957-964.

Mathews LS 1994 Activin receptors and cellular signaling by the receptor serine kinase family. Endocrine Reviews 15 310-325.

Mathews LS \& Vale WW 1991 Expression cloning of an activin receptor, a predicted transmembrane serine kinase. Cell 65973 982.

Matzuk MM, Finegold MJ, Su JG, Hsueh AJ \& Bradley A 1992

Alpha-inhibin is a tumour-suppressor gene with gonadal specificity in mice. Nature $360313-319$.

Mellor SL, Richards MG, Pedersen JS, Robertson DM \& Risbridger GP 1998 Loss of the expression and localization of inhibin alpha-subunit in high grade prostate cancer. Journal of Clinical Endocrinology and Metabolism 83 969-975.

Mellor SL, Cranfield M, Ries R, Pedersen J, Cancilla B, de Kretser D, Groome NP, Mason AJ \& Risbridger GP 2000

Co-localisation of activin betaC or betaA/betaB subunits in human prostate and evidence for formation of new activin betaC heterodimers. Journal of Clinical Endocrinology and Metabolism 85 (In Press).

Molloy CJ, Taylor DS \& Pawlowski JE 1999 Novel cardiovascular actions of the activins. Journal of Endocrinology 161 179-185.

Munz B, Hubner G, Tretter Y, Alzheimer C \& Werner S 1999 A novel role of activin in inflammation and repair. Journal of Endocrinology 161 187-193.

Nagai H, Pineau P, Tiollais P, Buendia MA \& Dejean A 1997 Comprehensive allelotyping of human hepatocellular carcinoma. Oncogene 14 2927-2933.

Nagle DL, McGrail SH, Vitale J, Woolf EA, Dussault BJ Jr, DiRocco L, Holmgren L, Montagno J, Bork P, Huszar D, Fairchild-Huntress V, Ge P, Keilty J, Ebeling C, Baldini L, Gilchrist J, Burn P, Carlson GA \& Moore KJ 1999 The mahogany protein is a receptor involved in suppression of obesity. Nature 398 148-152.

Oda S, Nishimatsu S, Murakami K \& Ueno N 1995 Molecular cloning and functional analysis of a new activin beta subunit: a dorsal mesoderm-inducing activity in Xenopus. Biochemical and Biophysical Research Communications 210 581-588.
Paralkar VM, Vail AL, Grasser WA, Brown TA, Xu H, Vukicevic S, Ke HZ, Qi H, Owen TA \& Thompson DD 1998 Cloning and characterization of a novel member of the transforming growth factor-beta/bone morphogenetic protein family. Journal of Biological Chemistry 273 13760-13767.

Phillips DJ \& de Kretser DM 1998 Follistatin: a multifunctional regulatory protein. Frontiers in Neuroendocrinology 19 287-322.

Piek E, Franzen P, Heldin CH \& ten Dijke P 1997 Characterization of a $60-\mathrm{kDa}$ cell surface-associated transforming growth factor-beta binding protein that can interfere with transforming growth factor-beta receptor binding. Journal of Cell Physiology $173447-459$.

Risbridger GP \& Cancilla B 2000 Role of activins in the male reproductive tract. Reviews of Reproduction 5 99-104.

Robertson DM, Foulds LM, Leversha L, Morgan FJ, Hearn MT, Burger HG, Wettenhall RE \& de Kretser DM 1985 Isolation of inhibin from bovine follicular fluid. Biochemical and Biophysical Research Communications 126 220-226.

Robertson DM, Klein R, de Vos FL, McLachlan RI, Wettenhall RE, Hearn MT, Burger HG \& de Kretser DM 1987 The isolation of polypeptides with FSH suppressing activity from bovine follicular fluid which are structurally different to inhibin. Biochemical and Biophysical Research Communications 149 744-749.

Saretzki G, Hoffmann U, Rohlke P, Psille R, Gaigal T, Keller G, Hofler H, Loning T, Petersen I \& Dietel M 1997 Identification of allelic losses in benign, borderline, and invasive epithelial ovarian tumors and correlation with clinical outcome. Cancer 80 $1241-1249$

van Schaik RH, Wierikx CD, Timmerman MA, Oomen MH, van Weerden WM, van der Kwast TH, van Steenbrugge GJ \& de Jong FH 2000 Variations in activin receptor, inhibin/activin subunit and follistatin mRNAs in human prostate tumour tissues. British Journal of Cancer 82 112-117.

SEER (Surveillence, Epidemiology and End Results) 1973-1995 Cancer Statistics Review. Bethesda, MD, USA: National Cancer Institute.

Sharma P \& Schreiber-Agus N 1999 Mouse models of prostate cancer. Oncogene 18 5349-5355.

Shi Y, Wang YF, Jayaraman L, Yang H, Massague J \& Pavletich NP 1998 Crystal structure of a Smad MH1 domain bound to DNA: insights on DNA binding in TGF-beta signaling. Cell 94 585-594.

Shikone T, Matzuk MM, Perlas E, Finegold MJ, Lewis KA, Vale W, Bradley A \& Hsueh AJ 1994 Characterization of gonadal sex cord-stromal tumor cell lines from inhibin-alpha and p53deficient mice: the role of activin as an autocrine growth factor. Molecular Endocrinology 8 983-995.

Shimonaka M, Inouye S, Shimasaki S \& Ling N 1991 Follistatin binds to both activin and inhibin through the common subunit. Endocrinology 128 3313-3315.

Steiner MS \& Barrack ER 1992 Transforming growth factor-beta 1 overproduction in prostate cancer: effects on growth in vivo and in vitro. Molecular Endocrinology 6 15-25.

Suarez B, Lin J, Burmester JK, Broman KW, Weber JL, Banerjee TK, Goddard KA, Witte JS, Elston RC \& Catalona WJ 2000 A genome screen of multiplex sibships with prostate cancer. American Journal of Human Genetics 66 933-944.

Sugino K, Kurosawa N, Nakamura T, Takio K, Shimasaki S, Ling N, Titani K \& Sugino H 1993 Molecular heterogeneity of follistatin, an activin-binding protein. Higher affinity of the carboxyl-terminal truncated forms for heparan sulfate 
proteoglycans on the ovarian granulosa cell. Journal of Biological Chemistry 268 15579-15587.

Teni TR, Sheth AR, Kamath MR \& Sheth NA 1988 Serum and urinary prostatic inhibin-like peptide in benign prostatic hyperplasia and carcinoma of prostate. Cancer Letters 43 9-14.

Thomas TZ, Wang H, Niclasen P, O’Bryan MK, Evans LW, Groome NP, Pedersen J \& Risbridger GP 1997 Expression and localization of activin subunits and follistatins in tissues from men with high grade prostate cancer. Journal of Clinical Endocrinology and Metabolism 82 3851-3858.

Thomas R, Anderson WA, Raman V \& Reddi AH $1998 a$ Androgen-dependent gene expression of bone morphogenetic protein 7 in mouse prostate. Prostate 37 236-245.

Thomas TZ, Chapman SM, Hong W, Gurusingfhe C, Mellor SL, Fletcher R, Pedersen J \& Risbridger GP $1998 b$ Inhibins, activins, and follistatins: expression of mRNAs and cellular localization in tissues from men with benign prostatic hyperplasia. Prostate 34 34-43.

Tsukazaki T, Chiang TA, Davison AF, Attisano L \& Wrana JL 1998 SARA, a FYVE domain protein that recruits Smad2 to the TGFbeta receptor. Cell 95 779-791.

Vaughan J \& Vale W 1993 Alpha2-macroglobulin is a binding protein of inhibin and activin. Endocrinology 132 2038-2050.

Wang QF, Tilly KI, Tilly JL, Preffer F, Schneyer AL, Crowley WF Jr \& Sluss PM 1996 Activin inhibits basal and androgen-stimulated proliferation and induces apoptosis in the human prostatic cancer cell line, LNCaP. Endocrinology 137 5476-5483.

Wang Q, Tabatabaei S, Planz B, Lin CW \& Sluss PM 1999 Identification of an activin-follistatin growth modulatory system in the human prostate: secretion and biological activity in primary cultures of prostatic epithelial cells. Journal of Urology 161 1378-1384.

Watson R, Roy W, Davis M, Hitchcock A \& Campbell IG 1997 Loss of heterozygosity at the alpha-inhibin locus on chromosome $2 \mathrm{q}$ is not a feature of human granulosa cell tumors. Gynecology and Oncology 65 387-390.
Woodruff TK 1998 Regulation of cellular and system function by activin. Biochemical Pharmacology 55 953-963.

Woodruff TK, Lyon RJ, Hansen SE, Rice GC \& Mather JP 1990 Inhibin and activin locally regulate rat ovarian folliculogenesis. Endocrinology 127 3196-3205.

Woodruff TK, Krummen LA, Lyon RJ, Stocks DL \& Mather JP 1993 Recombinant human inhibin A and recombinant human activin A regulate pituitary and ovarian function in the adult female rat. Endocrinology 132 2332-2341.

Wu RY, Zhang Y, Feng XH \& Derynck R 1997 Heteromeric and homomeric interactions correlate with signaling activity and functional cooperativity of Smad3 and Smad4/DPC4. Molecular and Cellular Biology 17 2521-2528.

Xu J, McKeehan K, Matsuzaki K \& McKeehan WL 1995 Inhibin antagonizes inhibition of liver cell growth by activin by a dominant-negative mechanism. Journal of Biological Chemistry $2706308-6313$.

Yamashita H, ten Dijke P, Huylebroeck D, Sampath TK, Andries M, Smith JC, Heldin CH \& Miyazono K 1995 Osteogenic protein-1 binds to activin type II receptors and induces certain activin-like effects. Journal of Cellular Biology 130 217-226.

Yamashita K, Yamoto M, Shikone T, Minami S \& Nakano R 1999 Immunohistochemical localization of inhibin and activin subunits in human epithelial ovarian tumors. American Journal of Obstetrics and Gynecology 180 316-322.

Ying SY 1988 Inhibins, activins, and follistatins: gonadal proteins modulating the secretion of follicle-stimulating hormone. Endocrine Reviews 9 267-293.

Zhang Z, Zhao Y, Batres Y, Lin MF \& Ying SY 1997 Regulation of growth and prostatic marker expression by activin $\mathrm{A}$ in an androgen-sensitive prostate cancer cell line LNCAP. Biochemical and Biophysical Research Communications 234 362-365.

Zheng W, Luo MP, Welt C, Lambert-Messerlian G, Sung CJ, Zhang Z, Ying SY, Schneyer AL, Lauchlan SC \& Felix JC 1998 Imbalanced expression of inhibin and activin subunits in primary epithelial ovarian cancer. Gynecology and Oncology 69 23-31. 